\title{
Managing Socio-Ethical Challenges in the Development of Smart Farming: From a Fragmented to a Comprehensive Approach for Responsible Research and Innovation
}

\author{
C. Eastwood ${ }^{1,3}(\mathbb{D})$ L. $\operatorname{Klerkx}^{2}(\mathbb{D}) \cdot$ M. $\operatorname{Ayre}^{3}\left(\mathbb{D} \cdot\right.$ B. Dela Rue $^{1}$
}

Accepted: 7 December 2017/Published online: 26 December 2017

(C) The Author(s) 2017. This article is an open access publication

\begin{abstract}
Smart farming (also referred to as digital farming, digital agriculture and precision agriculture) has largely been driven by productivity and efficiency aims, but there is an increasing awareness of potential socio-ethical challenges. The responsible research and innovation (RRI) approach aims to address such challenges but has had limited application in smart farming contexts. Using smart dairying research and development (R\&D) in New Zealand (NZ) as a case study, we examine the extent to which principles of RRI have been applied in NZ smart dairying development and assess the broader lessons for RRI application in smart farming. We draw on insights from: a review of research on dairy technology use in NZ; interviews with smart dairying stakeholders; and the application of an analytical framework based on RRI dimensions. We conclude that smart dairying R\&D and innovation activities have focused on technology development and on-farm use without considering socio-ethical implications and have excluded certain actors such as citizens and consumers. This indicates that readiness to enact RRI in this context is not yet optimal, and future RRI efforts require leadership by government or dairy sector organisations to fully embed RRI principles in the guidelines for large R\&D project design (what has also been referred to as 'RRI maturity'). More broadly, enacting RRI in smart farming requires initial identification of RRI readiness in a given sector or country and devising a roadmap and coherent project portfolio to support capacity building for enacting RRI. Additionally, methods (such
\end{abstract}

$\triangle$ L. Klerkx

laurens.klerkx@wur.nl

1 DairyNZ, Private Bag 3221, Hamilton 3240, New Zealand

2 Knowledge, Technology and Innovation Group, Wageningen University, Wageningen, The Netherlands

3 Rural Innovation Research Group, Faculty of Veterinary and Agricultural Sciences, University of Melbourne, Parkville, VIC 3010, Australia 
as RRI indicators) for operationalising RRI must be adapted to the context of the national or sectoral innovation system in which smart farming is being developed.

Keywords Smart farming · Digital farming · Ethics $\cdot$ RRI indicators · Big data - Internet of things · Pasture-based dairying - AKIS - Digital agriculture . Precision agriculture

\section{Introduction}

Smart farming (also referred to as digital farming, digital agriculture and precision agriculture) has been proposed to manage land, animals, and farm personnel more effectively (Tey and Brindal 2012; Wolfert et al. 2017). The smart farming approach implies that farm management tasks and upstream interactions in the supply chain are informed by collected data, enhanced by context and situation awareness, and triggered by real-time events (Wolfert et al. 2014; Wolfert et al. 2017). A range of sensors are used to collect these data to monitor animals, soil, water, and plants (Eastwood et al. 2012; Jago et al. 2013; Scholten et al. 2013). The data are used to interpret the past and predict the future to ensure more timely or accurate decision making both on-farm and in the supply chain (Carbonell 2016; Wolfert et al. 2017), where the accumulation of data from different farms also enables so-called Big Data analysis (Bronson and Knezevic 2016). Scientists and policymakers are increasingly looking to smart farming as a technological solution to address societal concerns around farming, including provenance and food traceability (Dawkins 2017), animal welfare in livestock industries (Yeates 2017), and the environmental impact of different farming practices (Busse et al. 2015; Wolfert et al. 2017; Carolan 2016).

Despite opportunities associated with smart farming in terms of improved productivity and positive environmental outcomes through more precise input use (Kaloxylos et al. 2012; Wolfert et al. 2017), smart farming potentially entails negative outcomes. Most smart farming literature focuses on the potential for improving agricultural practices and productivity (Wathes et al. 2008; Rutten et al. 2013), but some scholars have investigated the socio-ethical implications (Millar 2000; Wolf and Wood 1997; Carbonell 2016; Driessen and Heutinck 2015). These socio-ethical challenges in smart farming have been recognised at the level of the farm, the wider farming community, and society (Bos and Munnichs 2016). It has been argued that smart farming will reshape the practice of farming, with less 'hands-on' management and a more data-driven approach (Eastwood et al. 2012). Different skills will be required across the farming team to enact and adapt smart farming technologies (Eastwood et al. 2017b; Higgins et al. 2017), along with adapted advisory structures, potentially leading to displaced farm staff and service providers. Such changes could have a major impact on the cultural fabric of what it means to be a farmer (Burton et al. 2012; Carolan 2016), with the independence of managing 'your farm, your way' replaced with a far more structured and scrutinised 
approach, for example through detailed monitoring by agricultural equipment makers, input suppliers, processors and retailers (Bronson and Knezevic 2016).

The widespread use of smart dairy farming technologies (the empirical focus of this paper) presents both potential issues and opportunities, for example with robotic milking systems (Driessen and Heutinck 2015) and the use of technologies to replace animal husbandry tasks (Butler and Holloway 2016). Robotic milking adoption has been shown to involve varied outcomes for animals (e.g. levels of cow freedom), people (e.g. skills required of farm staff), and the environment (e.g. implications of intensification) (Schewe and Stuart 2014). Studies have also highlighted a technology-driven change in the relationship between cows and farmers (Driessen and Heutinck 2015; Holloway et al. 2014; Schewe and Stuart 2014). Driessen and Heutinck (2015) therefore identify a moral challenge in the ethics surrounding where technology ends and the animal begins in robotic milking; this may trigger debates in society around animal welfare.

These issues represent challenges for smart farming research and innovation and the further diffusion of smart farming technologies in terms of anticipating, and preventing, potential negative consequences (Wigboldus et al. 2016; Bronson and Knezevic 2016). These challenges are further complicated by the fast-moving and commercially driven nature of smart technology development (Eastwood et al. $2017 b$ ). It has been argued that research and innovation should incorporate societal values, needs, and expectations such as: privacy; use of information; sustainability; human reproduction; gender, minorities, and justice; power and control; impact on social contact patterns and human values; and international relations (Hellström 2003; Skorupinski 2002; Wigboldus et al. 2016; Palm and Hansson 2006; Bronson and Knezevic 2016). A desire to anticipate the implications of research and innovation better and to incorporate continuous responsiveness to societal concerns has led to the development of responsible research and innovation (RRI) (Stilgoe et al. 2013; von Schomberg 2011).

RRI has its roots in a European social and political setting, and, to date, most studies on the application of RRI have been undertaken within European or North American contexts (Stilgoe et al. 2013; von Schomberg 2011; Wiek et al. 2016; Guston 2014a, b), on topics such as nanotechnology and information and communication technology (ICT). However, similar concerns over the ethical implications of innovation are emerging globally, with questions raised on RRI application in different social, political, and cultural settings (Macnaghten et al. 2014), requiring exploration of RRI implementation in other settings. Studies on RRI enactment are still limited in agriculture and, although the number has grown in recent years (Asveld et al. 2015; Bruijnis et al. 2015; Bronson 2015; Macnaghten 2016; Macnaghten et al. 2014; Wigboldus et al. 2016), they do not focus specifically on smart farming. Furthermore, it has been argued that understanding issues around the practical implementation of RRI in commercially driven and corporate contexts such as smart farming requires more research attention (Blok and Long 2016; Stahl et al. 2017; Blok et al. 2015). Acquiring insights into RRI around smart farming is timely, for example to inform current European projects that include foresight exercises for precision agriculture (Schrijver et al. 2016), mapping and supporting the Agricultural Knowledge and Innovation System (AKIS) for smart farming (see 
https://www.smart-akis.com) and the application of the Internet of Things in farming (IoF2020 2017), or large efforts in this space in Australia (the Digiscape programme led by CSIRO) and France (the \#DigitAg programme).

We aim to address these research gaps by assessing smart dairying development in New Zealand (NZ) from an RRI perspective, where there are emerging issues around the implications of innovation for personnel, animals, and the environment (Jay 2007; Saunders et al. 2016). Although these issues are already reflected in research and innovation projects in NZ smart dairying development, it is questionable how comprehensive these have been from an RRI perspective. Insights on the application of the RRI concept—or the lack of it-may thus be useful to aid in anticipating implications and responding to societal needs in respect of smart farming in NZ and to improve processes to enable the enactment of mutual responsiveness among stakeholders (Blok and Lemmens 2015). The insights gained may be helpful beyond the NZ dairy sector for the application of a comprehensive RRI approach in smart farming more broadly, and in different national contexts. The paper therefore focuses on two questions:

- To what extent, and why, have elements of RRI been considered to date to address socio-ethical challenges in NZ smart dairying development?

- What are the broader lessons for RRI application in smart farming?

We address these questions through a review of research projects focused on technology use in NZ dairy farming, in addition to interviews with stakeholders in smart dairying. We first review the literature on RRI dimensions and indicators to assess its application. From this review, we draw an analytical framework to assess smart dairying that will guide the interpretation of our findings.

\section{Assessing Responsible Research and Innovation in Smart Farming}

\section{RRI Dimensions and Indicators}

RRI, which is aimed at guiding socially and ethically acceptable innovation (Stilgoe et al. 2013), has links with concepts such as technology assessment (TA) and corporate social responsibility (CSR) (Iatridis and Schroeder 2016). RRI extends the TA concept to ethical issues of responsibility (Grunwald 2014) and broader processes for including public perspectives (Pellé and Reber 2013). CSR includes aspects such as identifying stakeholder concerns, understanding environmental and social impacts on a business, and the standards adopted to minimise impacts-also addressed in RRI (Hemphill 2016). However, RRI extends beyond approaches such as CSR and TA, particularly in terms of proactive anticipation of potential consequences of innovation and a greater responsiveness to changing societal norms (Wickson and Carew 2014).

There have been a range of conceptualisations of RRI, including the anticipationinclusion-reflexivity-responsiveness (AIRR) framework (Owen et al. 2013; Stilgoe et al. 2013), to which a fifth element transparency is sometimes added (Ravn et al. 
2015). The conceptualisation in the European Union RRI tools project describes the dimensions as diverse and inclusive, anticipative and reflective, open and transparent, and responsive and adaptive (Groves 2017). Another approach involves five RRI keys: engagement of all societal actors, gender equality, science literacy and education, open access, and ethics, with governance sometimes added as an additional key (Ravn et al. 2015). In this paper, we base our analysis on the AIRR framework as it provides a simple structural framework against which to assess whether smart dairying in NZ includes aspects of RRI.

The broad-ranging aims and undefined implementation methods of the proposed RRI approach have led scholars to question its practical applicability (Blok and Lemmens 2015). To enhance RRI application, indicators have been devised to monitor and assess RRI enactment. Wickson and Carew (2014), for example, developed seven quality criteria in an RRI performance rubric with examples of criteria from exemplary to routine. Also, Ravn et al. (2015) outlined the construction of 36 indicators guided by a set of criteria including: potential for sustained data collection, RRI conceptual coverage, representation of targeted actors and stakeholders (including all $28 \mathrm{EU}$ member states), use of input-and output-based indicators, use of qualitative and quantitative data, with a range of quality criteria applied. In the development of the framework presented below, we describe each of the AIRR dimensions along with examples of indicators proposed in previous studies.

\section{Framework for the Analysis of RRI in Smart Dairying}

Drawing on discussions on RRI by authors such as Stilgoe et al. (2013), Blok and Lemmens (2015), Stahl et al. (2016), Asveld et al. (2015), and the indicators developed by Wickson and Carew (2014) and Ravn et al. (2015), we propose initial indicators for RRI in smart dairying (Table 1). We then use these indicators to guide our assessment of whether the AIRR dimensions have been addressed in NZ smart dairying research and development $(\mathrm{R} \& \mathrm{D})$ activities.

\section{Anticipation}

To enhance anticipation in science and innovation governance, actors (e.g. researchers, professional practitioners, technology developers, and policymakers) should use processes to identify and minimise unintended consequences of future innovation. Potential indicators of anticipatory processes include the use of foresight exercises, horizon scanning, and scenario-building techniques (Stilgoe et al. 2013). Such future-casting processes should be applied at various times throughout the R\&D project, with both positive and negative scenarios envisaged (Wickson and Carew 2014).

\section{Inclusion}

Inclusion, or participation, relates to broadening the debates around innovation from top-down governance mechanisms and the inclusion of stakeholders (Ravn et al. 2015) to a broader involvement of stakeholders (including the public) through 
Table 1 Proposed indicators of responsible innovation activities in smart dairying, based on the RRI literature (Asveld et al. 2015; Blok and Lemmens 2015; Ravn et al. 2015; Stahl et al. 2016; Stilgoe et al. 2013; Wickson and Carew 2014)

\begin{tabular}{|c|c|c|c|}
\hline & Indicator & Description & Potential activities \\
\hline & \multicolumn{3}{|l|}{ Anticipation } \\
\hline 1 & Foresight exercises & $\begin{array}{l}\text { Future-scanning activities are } \\
\text { undertaken to identify potential } \\
\text { economic, social, and } \\
\text { environmental implications } \\
\text { associated with smart dairying }\end{array}$ & $\begin{array}{l}\text { Technology-use surveys, assessing } \\
\text { farmer perceptions of } \\
\text { technology, public opinion } \\
\text { surveys }\end{array}$ \\
\hline 2 & $\begin{array}{l}\text { Scenario building of } \\
\text { smart dairy futures }\end{array}$ & $\begin{array}{l}\text { Processes used to imagine potential } \\
\text { positive and negative futures } \\
\text { (e.g. changing role of farmers) } \\
\text { where technology use is } \\
\text { prevalent on NZ dairy farms }\end{array}$ & $\begin{array}{l}\text { Visioning of smart dairy farms, } \\
\text { assessing potential social, } \\
\text { animal, and environmental } \\
\text { outcomes }\end{array}$ \\
\hline & \multicolumn{3}{|l|}{ Inclusion } \\
\hline 3 & $\begin{array}{l}\text { Involvement of relevant } \\
\text { actors }\end{array}$ & $\begin{array}{l}\text { A range of end-users and citizens } \\
\text { are involved in socio-ethical } \\
\text { discussions, for example relating } \\
\text { to animal-technology interactions } \\
\text { and farmer-technology } \\
\text { interactions }\end{array}$ & $\begin{array}{l}\text { Actively seeking critical feedback } \\
\text { in workshops with stakeholders, } \\
\text { use of citizen panels or online } \\
\text { forums }\end{array}$ \\
\hline 4 & $\begin{array}{r}\text { Private sector } \\
\text { engagement }\end{array}$ & $\begin{array}{l}\text { Private companies are included as } \\
\text { partners in publicly funded smart } \\
\text { dairying R\&D projects }\end{array}$ & $\begin{array}{l}\text { Private companies co-fund } \\
\text { projects, private sector } \\
\text { represented in project } \\
\text { governance }\end{array}$ \\
\hline 5 & $\begin{array}{l}\text { Encouraging } \\
\text { transformative mutual } \\
\text { learning }\end{array}$ & $\begin{array}{l}\text { Processes exist for multiple } \\
\text { stakeholders to engage in mutual } \\
\text { learning within } R \& D \text { projects }\end{array}$ & $\begin{array}{l}\text { User-centred design, open } \\
\text { innovation, and co-innovation }\end{array}$ \\
\hline & \multicolumn{3}{|l|}{ Reflexivity } \\
\hline 6 & Reflexive guidance & $\begin{array}{l}\text { Processes to guide reflection within } \\
\text { research teams on underlying } \\
\text { assumptions and values around } \\
\text { development and use of } \\
\text { technology }\end{array}$ & $\begin{array}{l}\text { Reflexive monitors used in project } \\
\text { (i.e. persons dedicated to } \\
\text { facilitating reflection) }\end{array}$ \\
\hline 7 & $\begin{array}{l}\text { Structures guide second- } \\
\text { order reflexivity }\end{array}$ & $\begin{array}{l}\text { Reflexivity is embedded in } \mathrm{R} \& \mathrm{D} \\
\text { projects using processes such as } \\
\text { codes of conduct and standards }\end{array}$ & $\begin{array}{l}\text { Creation of, and engagement with } \\
\text { codes of conduct, best practice } \\
\text { guidelines }\end{array}$ \\
\hline & \multicolumn{3}{|l|}{ Responsiveness } \\
\hline 8 & $\begin{array}{l}\text { Potential to adapt } \\
\text { projects }\end{array}$ & $\begin{array}{l}\text { Smart dairying R\&D projects have } \\
\text { the ability to change direction } \\
\text { based on stakeholder feedback }\end{array}$ & $\begin{array}{l}\text { Stage-gating, mid-project reviews, } \\
\text { structures for adapting } \\
\text { milestones and deliverables }\end{array}$ \\
\hline 9 & $\begin{array}{l}\text { Open research processes } \\
\text { and access to research } \\
\text { data }\end{array}$ & $\begin{array}{l}\text { The design of smart dairy R\&D is } \\
\text { transparent, and the processes are } \\
\text { accessible to private companies, } \\
\text { farmers, and communities }\end{array}$ & $\begin{array}{l}\text { Open data exchange, open access } \\
\text { to research results, declaring } \\
\text { conflicts of interest }\end{array}$ \\
\hline
\end{tabular}


small-group processes and other methods. The inclusion of stakeholder perspectives in technology development has been suggested as a method for improving stakeholders' trust in the innovation process (Asveld et al. 2015). Wickson and Carew (2014) identified the conscious use of transdisciplinary processes, openly and actively seeking critical input, and encouraging transformative mutual learning as exemplars of diverse processes. Techniques to facilitate inclusion include citizen panels, focus groups, lay representation on governance groups, and user-centred design (Stilgoe et al. 2013).

\section{Reflexivity}

Being more reflexive involves researchers assessing their own motivations and assumptions (e.g. social, ethical, and political norms and values) and acknowledging the perspectives of other actors (e.g. the public, companies) on particular issues (Pellé and Reber 2013). Certification and standardisation have been identified as ways for public and private institutions to communicate their norms (Asveld et al. 2015). Codes of conduct and standards can also facilitate second-order reflexivity, where the underlying values shaping research and innovation are scrutinised 'by drawing connections between external value systems and scientific practice' (Stilgoe et al. 2013, p. 1571); this also helps to build trust with the community and other organisations (Asveld et al. 2015). In RRI, reflexivity therefore becomes a public matter, and embedding social scientists in projects helps to facilitate the reflexive process (Stilgoe et al. 2013).

\section{Responsiveness}

Responding to societal needs requires the ability - applying a deliberative attitude (Asveld et al. 2015) — to change direction in the innovation process in light of emerging knowledge and perspectives. Stilgoe et al. (2013) saw the response to major societal challenges (e.g. climate change) as an indication of the responsiveness of innovation processes. Societal challenges, perspectives, and norms also change over time, so responsible innovation also needs to have the capacity to change direction or scope through techniques such as stage-gates (Stilgoe et al. 2013). Open access to research processes and results, along with declarations of conflicts of interest, are also potential responsive approaches, as they enable the public to respond to results and influence subsequent research directions (Stilgoe et al. 2013; Wickson and Carew 2014; Ravn et al. 2015).

\section{Method}

\section{Timeline Analysis of Research and Development Activities in NZ Smart Dairying}

In this paper, we used a timeline analysis methodology, as adopted by other studies (Hekkert and Negro 2009; Klerkx et al. 2012; Eastwood et al. 2017b), to analyse 
Table 2 Dataset 1-published studies on smart dairying in NZ analysed

1-The Greenfield project, application of robotic milking in pasture-based dairy (Woolford et al. 2004)

2-Pastures from Space ${ }^{\mathrm{TM}}$ project developing satellite-based pasture measurement (Clark et al. 2006)

3-Overview of opportunities and risks associated with technology use in dairy farming. Two wholeday workshops held in 2011 between dairy sector representatives, researchers, and farmers from NZ and Australia (Jago et al. 2013)

4-Examining the use of pasture measurement technologies via interviews with 15 dairy farmers and service providers throughout NZ (Eastwood and Yule 2015)

5-Survey of 83 dairy farmers on factors including the reasons for investment in technology, initial expectations of benefits, and the impact/benefits of technology (Eastwood et al. 2016)

6-A survey in 2013 of 42 farmers, followed by interviews with 32 farmers and five farm consultants, regarding the use of individualised feeding technology on NZ dairy farms (Dela Rue and Eastwood 2017)

7-Two smart dairying technology-use surveys in 2008 and 2013 of 528 and 500 dairy farmers, respectively—see Edwards et al. (2015)

8-Interviews about the use of precision grazing technologies in 2015-16 with 12 dairy farmers and five farm consultants, and a workshop with technology developers (Eastwood et al. 2017a)

key research and development activities relating to smart dairying in NZ. Using a timeline method facilitates the identification of events associated with developing technologies and can aid the classification of trends. For this, we drew on two different data sources, as described in Tables 2 and 3. Dataset 1 involves published studies (termed Studies 1-8) on major smart dairying R\&D projects in NZ that were reviewed to uncover activities and issues relating to responsible innovation. Dataset 2 consists of semi-structured interviews conducted with 10 key stakeholders acting as informants, giving their broad perspective regarding dairy technology use and research and innovation governance in the NZ dairy sector.

\section{Semi-Structured Interview Approach}

The semi-structured interview participants were selected through a purposive sampling strategy, with the aim of selecting highly knowledgeable and connected informants with broad experience in smart dairying issues. The interviews, conducted in January to March 2017, were approximately $60 \mathrm{~min}$ in duration and conducted by the same interviewer throughout (the first author of this paper). Verbatim notes were collected, supported by voice recordings, and were analysed for themes using NVIVO 10 software. The interviews were based on three themes: adoption of smart dairy technologies in research and development projects; current barriers and opportunities for the use of smart dairying; and foresight exercises on important considerations for future governance of smart dairying (including infrastructure, skills, ethical issues, social acceptability, regulation, and policy). These themes were chosen firstly to explore the current use of smart dairy technology and understand current socio-ethical issues, and then to triangulate knowledge on R\&D activities from the review (Table 2), before focusing on issues relating to governance. 
Table 3 Dataset 2-background on participants in semi-structured interviews investigating R\&D projects based on smart dairying technologies, current issues, and considerations for the future governance of smart dairying

\begin{tabular}{|c|c|}
\hline Role & Experience and responsibility \\
\hline Smart farming researcher & $\begin{array}{l}\text { Research leader in precision agriculture with over } 25 \text { years' international } \\
\text { experience and a focus on technology applications for sustainable } \\
\text { agriculture }\end{array}$ \\
\hline Smart farming researcher & $\begin{array}{l}\text { Farming systems researcher with over } 20 \text { years' experience at a major NZ } \\
\text { agricultural research organisation. Research has included applying } \\
\text { precision dairy technologies on a farm scale }\end{array}$ \\
\hline Dairy animal welfare expert & $\begin{array}{l}\text { Led the animal welfare programme for a dairy farmer-levy organisation in } \\
\text { NZ. Worked closely with farmers and government in responding to } \\
\text { community animal welfare concerns }\end{array}$ \\
\hline Dairy environmental expert & $\begin{array}{l}\text { Led the sustainability programme for a dairy farmer-levy organisation in } \\
\text { NZ. Developed data capture processes for environmental, welfare, and } \\
\text { social proof of practice on dairy farms }\end{array}$ \\
\hline Agri-consumer researcher & $\begin{array}{l}\text { Has over } 30 \text { years' research experience in agricultural trade in NZ and } \\
\text { internationally, particularly the influence of consumers, policy, the } \\
\text { environment, and new technologies }\end{array}$ \\
\hline Technology developer & $\begin{array}{l}\text { Responsibilities include installation and sales of smart dairy technology, } \\
\text { and over } 20 \text { years' experience with technology in dairy }\end{array}$ \\
\hline Technology developer & $\begin{array}{l}\text { Responsibilities include strategic decision making for a livestock } \\
\text { management and technology company servicing NZ and over } 100 \text { other } \\
\text { countries }\end{array}$ \\
\hline $\begin{array}{l}\text { Milk processing company } \\
\text { representative }\end{array}$ & $\begin{array}{l}\text { An R\&D manager for a small milk-processing company in NZ, with } \\
\text { experience in data capture for quality assurance programmes }\end{array}$ \\
\hline $\begin{array}{l}\text { Milk processing company } \\
\text { representative }\end{array}$ & $\begin{array}{l}\text { An } \mathrm{R} \& \mathrm{D} \text { manager for a major milk processing company in } \mathrm{NZ} \text {, with a } \\
\text { focus on technology use in dairying }\end{array}$ \\
\hline Agri-business professional & $\begin{array}{l}\text { The main rural economist for a major NZ bank, with over } 10 \text { years' } \\
\text { experience in agri-economics. Special interest in the role of new } \\
\text { technologies and data in agriculture }\end{array}$ \\
\hline
\end{tabular}

\section{Findings and Discussion: Analysis of RRI Activities and RRI Gaps}

In this section, we present and discuss the findings from the review of previous studies and the insights from informants. First, we describe the main issues facing the NZ dairy industry and relate these to smart dairying R\&D activities. We then explore socio-ethical challenges associated with smart dairying uncovered in our analysis and informant interviews, and we identify examples of RRI activities, using the indicators in the analytical framework (Table 1). Finally, we identify gaps and lessons in respect to RRI application in this context, including why RRI dimensions have, or have not, been applied.

\section{Issues Facing NZ Dairy Farming}

Our case study is based on the NZ dairy industry, and therefore context relating to the issues facing dairy farming is presented here. New Zealand's economic prosperity in the last century was delivered by agriculture, and in the past 20 years 
Table 4 Major social, ethical, environmental, and financial issues facing NZ dairy farming, the smart dairying R\&D activities in relation to each issue (identified by the R\&D project analysis, informants, and supported by literature)

\begin{tabular}{|c|c|c|}
\hline Challenge & Description of issues & $\begin{array}{l}\text { Smart dairying } R \& D \text { and innovation } \\
\text { activities relating to each issue }\end{array}$ \\
\hline
\end{tabular}

Economics and viability

Environment

\begin{abstract}
Attracting and retaining skilled people
\end{abstract}

Lifestyle and business
The NZ dairy industry is dependent on exported commodity products (e.g. whole milk powder). The volatility in whole milk powder markets in the past decade has presented a major challenge to dairy farm viability and resilience (Wales and Kolver 2017). There has been a renewed focus on increasing farm productivity and providing tools to enhance profitability

Intensified dairying in NZ, growing from 3.5 million cows in 2000 to 5 million cows in 2015 (LIC \& DairyNZ 2016), has been linked to concerns over water quality and quantity, greenhouse gas emissions, and soil conservation (Jay 2007; Chobtang et al. 2017; Doole and Romera 2015)

Farmers have struggled to source skilled staff, with migrants with little prior experience of dairying often now employed (Tipples and Wilson 2005), leading to issues around farm management skills, animal husbandry, and staff retention

NZ farms were traditionally family owned and operated (Burton et al. 2012). Now with larger farms, more staff but less family labour, and increased regulations and compliance, farmers operate more as business managers of small to mediumsized enterprises and manage larger networks, in addition to technology providers. Changing roles for farmers and expanding information networks mean that farmers have to process much more information than in previous generations
In 2010, a 7-year precision dairy project was funded through farmer levies and the government as part of a Primary Growth Partnership (PGP) programme (P6, 8, 10, 11, 12 in Fig. 1) to assess use of smart dairy technologies for productivity improvements

Pastures from Space project (P3), a project (with funding from the government, farmer levies, and a milk processing company) using satellite imagery to remotely measure pasture

The Rapid Pasture Meter (P2) codeveloped at Massey University in 2002, with a local commercial company.

Massey University PhD study (P5) focused on sensors to measure nitrogen deposition from dairy cows (Draganova et al. 2016)

A NZD \$19.5 million, 7-year PGP programme funded by government and a fertiliser company started to develop technologies to manage nutrient inputs (P7)

Optimum N (P9), a NZD \$6.3 million project funded by the government in 2012 to develop N-sensing technologies

A 7-year Greenfield robotic milking project $(\mathrm{P} 1)$ was driven by a desire to reduce hours spent milking and to make dairy more appealing as a career

The Greenfield project (P1) focused on adapting robotic milking to a pasturebased grazing system to improve lifestyle 
Table 4 continued

\begin{tabular}{|c|c|c|}
\hline Challenge & Description of issues & $\begin{array}{l}\text { Smart dairying } R \& D \text { and innovation } \\
\text { activities relating to each issue }\end{array}$ \\
\hline $\begin{array}{l}\text { Community } \\
\text { acceptance and } \\
\text { connection }\end{array}$ & $\begin{array}{l}\text { Non-farming public were historically } \\
\text { connected to farmers, often through direct } \\
\text { family links. A growing rural-urban divide } \\
\text { has impacted this understanding, due to } \\
\text { population growth and urbanisation, also a } \\
\text { trend internationally (Boogaard et al. 2011; } \\
\text { Grandin 2014). The broader public (and } \\
\text { media) in NZ have expressed concerns } \\
\text { about the impacts of intensification (Jay } \\
\text { 2007; Burton et al. 2012) }\end{array}$ & $\begin{array}{l}\text { The Greenfield project (P1) involved } \\
\text { some minor activities aimed at linking } \\
\text { the community with farming practice } \\
\text { through automated milking open days }\end{array}$ \\
\hline Animal welfare & $\begin{array}{l}\text { National and international consumers, and } \\
\text { consequently the NZ government, have also } \\
\text { demanded greater scrutiny and proof of } \\
\text { farm practice relating to animals and the } \\
\text { environment (Jay 2007; Saunders et al. } \\
\text { 2016) }\end{array}$ & $\begin{array}{l}\text { As part of the Greenfield (P1) and the } \\
\text { Precision Dairy PGP (P6) projects, there } \\
\text { were activities to assess the use of } \\
\text { technologies to monitor animal health } \\
\text { and reproduction status }\end{array}$ \\
\hline $\begin{array}{l}\text { Technology } \\
\text { performance } \\
\text { and } \\
\text { infrastructure }\end{array}$ & $\begin{array}{l}\text { Adoption is limited by uncertain value, poor } \\
\text { inter-technological integration, mismatch } \\
\text { with farming systems, lack of national } \\
\text { infrastructure or core enabling technologies, } \\
\text { e.g. automated pasture measurement } \\
\text { (Eastwood et al. 2017a) }\end{array}$ & $\begin{array}{l}\text { The Precision Dairy PGP project } \\
\text { (P6,8,10,11,12) also focused on } \\
\text { dilemmas around technology meeting } \\
\text { farmer needs, data privacy and sharing } \\
\text { issues, and relationships between public } \\
\text { and private R\&D organisations } \\
\text { Technology-use surveys }(\mathrm{P} 4,10) \text { were } \\
\text { conducted to ascertain current and } \\
\text { expected smart dairying uptake, along } \\
\text { with issues that farmers were } \\
\text { experiencing }\end{array}$ \\
\hline
\end{tabular}

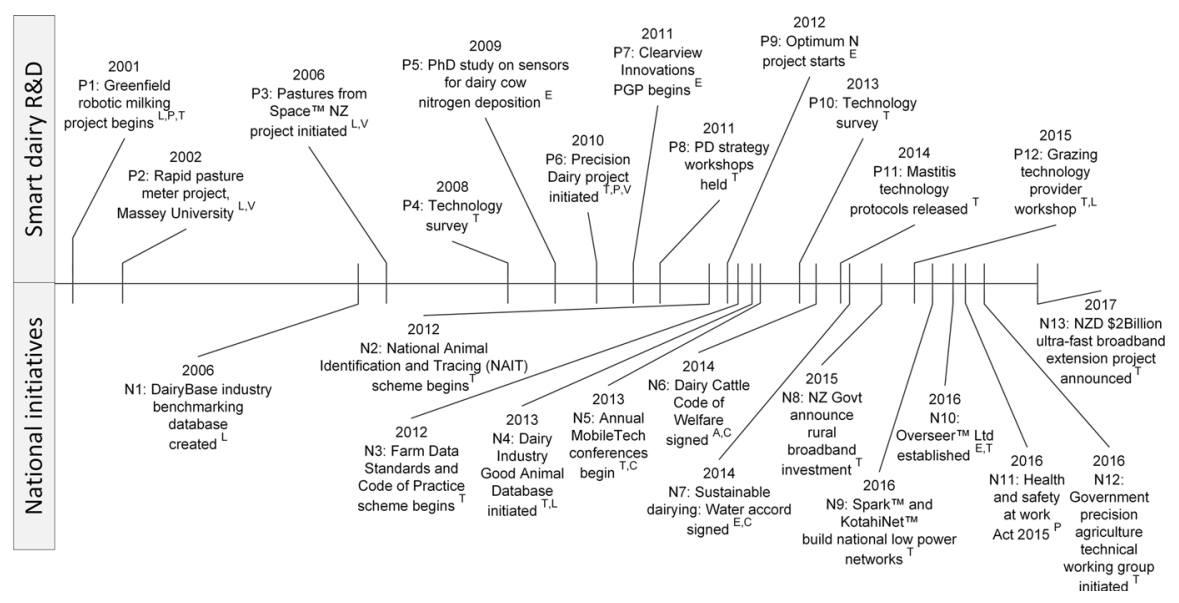

Fig. 1 Timeline diagram of major innovation events via R\&D projects (labelled P1-P12) and related national initiatives (labelled N1-N13) in NZ smart dairying (2000-2017). Events are also linked to relevant issues from Table 4 by the following superscripts: ${ }^{\mathrm{V}}$ Economics and viability, ${ }^{\mathrm{E}}$ Environment, ${ }^{\mathrm{P}}$ Attracting and retaining people, ${ }^{\mathrm{L}}$ Lifestyle and business, ${ }^{\mathrm{C}}$ Community acceptance and connection, ${ }^{\mathrm{A}}$ Animal welfare, and ${ }^{\mathrm{T}}$ Technology performance and national infrastructure 
dairy farming has been a significant export industry. Ambitious business growth targets, recently set by the NZ government, include doubling primary industry exports in real terms from 2012 to 2025 through value-added products and productivity improvements (Ballingall and Pambudi 2017). Innovation and technology-based solutions are seen as central to achieving these growth targets; however, the broader consequences of technology-driven farming have rarely been considered in the NZ context. Intensification in dairy farming is linked with a range of issues (Table 4), for example increased pressure on water quality (Jay 2007). There are also issues associated with attracting and retaining staff, health and safety on farms, maintaining a viable business while enjoying the farming lifestyle, meeting evolving animal welfare expectations, and meeting community and consumer expectations in general (Tipples and Wilson 2005; Jay 2007; Burton et al. 2012). To address these issues, $R \& D$ projects have been set up, as discussed in the next section.

\section{Development of Smart Dairying R\&D Projects in NZ}

Informants noted that the commercial imperative of low-cost, grazed pasture systems has driven NZ farmers to remain relatively low-tech compared with their counterparts on European and North American dairy farms (Kamphuis et al. 2016). Labour-saving devices (e.g. automated cup removers, automated feeding) have proven most popular among dairy farmers internationally (Borchers and Bewley 2015; Eastwood et al. 2016), and this is mirrored in NZ (Edwards et al. 2015). In NZ, the uptake of the more complex (and expensive) technologies, such as robotic milking, has not proved popular because of lower costs of conventional milking and issues of scale, with only approximately 20 farms using milking robots by 2016. Informants noted that increased technology use will be required to enable dairy farmers to manage the issues listed in Table 4. They also noted that greater data collection will be required to provide proof of good management practice for environmental reporting. Technologies such as virtual fencing (Umstatter 2011), low power wireless networks, and robotic milking in rotary parlours (Kolbach et al. 2012) were identified as smart dairying innovations with an important role on future NZ dairy farms.

Increased interest in NZ regarding the potential use of smart dairying has led to the funding of several major R\&D projects in the past 15 years. The projects included R\&D focused on: adapting farming systems around robotic milking (P1 in Fig. 1); developing systems to use satellite imagery to measure pasture (P3); developing pasture measurement technology (P2); assessing technology efficacy and return on investment, and addressing issues around smart dairying $(\mathrm{P} 4,6,8,10$, 11, 12); developing nutrient management technologies (P7); and developing nitrogen-sensing technologies (P5, 9). We have linked the R\&D projects to the relevant issue (Table 4). However, although we have identified significant initiatives, there may also be some smaller projects not identified here. Additionally, community acceptance and connection and animal welfare have no dedicated smart dairying projects, but these issues may be addressed through other non-technology based projects. 
Table 5 National initiatives with implications for smart dairy development in NZ

N1-DairyBase, a dairy industry financial and environmental benchmarking database, began in 2006

N2-The compulsory national identification and traceability (NAIT) scheme was introduced nationally in 2012, using electronic identification (EID) ear-tag technology to track farm-to-farm or farm-to-abattoir cattle movements. This technology acted as an enabler for other smart devices such as automated sorting, walk-over weighing, and milk meters, which rely on EID. It also enabled traceability for compliance and disease control

N3-Projects including Farm Data Standards (setting a common data vocabulary to allow easier data exchange) and a Farm Data Code of Practice and a Data Linker project were initiated in the primary industries. The code of practice requires organisations to outline how they safeguard farmer data. It was developed with farmer representative organisations, private companies, and milk processing companies

N4-The Dairy Industry Good Animal Database development began in 2013

N5-Researcher- and technology developer-focused forums for the discussion of smart technology development (including dairy) included the annual MobileTech conferences

N6-A Dairy Cattle Code of Welfare 2016 encourages all those responsible for dairy cattle to adopt the highest standards of husbandry, care, and handling

N7-The Sustainable Dairying: Water Accord is a set of national good management practice benchmarks aimed at lifting environmental performance on dairy farms

N8-An investment in rural broadband by the government began in 2015 to improve rural internet connectivity and mobile coverage.

N9-Around 2016, two initiatives sought to apply low power wide area networks across NZ and included a focus on agricultural use

N10-OVERSEER ${ }^{\mathrm{TM}}$ Limited was developed as a joint venture by the Ministry for Primary Industries, AgResearch Limited (a government-owned research organisation), and the Fertiliser Association of NZ. OVERSEER ${ }^{\mathrm{TM}}$ is a farm-scale nutrient model, adopted as a tool for achieving optimal nutrient use for increased profitability and managing within environmental limits. It is being used in some areas of NZ as a tool to determine whether farmers are operating within regulatory rules

N11-The Health and Safety at Work Act 2015 has also had immediate technological implications with the development of Apps and online systems to track health and safety compliance, incidents, and hazard identification

N12-In 2016, the NZ Government formed a smart agriculture technical advisory group potentially signifying greater government interaction with smart dairying issues and offering an opportunity to begin a broader national discussion about socio-ethical considerations associated with smart farming

N13-The rural broadband scheme (N8) was expanded in 2017

\section{National Innovation Initiatives Beyond R\&D Projects Relating to Smart Dairy Development}

Our timeline analysis (Fig. 1) and overview in Table 4 highlight how the focus of NZ smart dairying R\&D projects has been on technology development. However, innovation is also about simultaneous and interconnected changes in infrastructures and social and institutional structures (Kilelu et al. 2013; Geels 2004) in addition to R\&D. Therefore, smart dairying development has been supported by several important national initiatives focusing on infrastructure and institutional structures. These initiatives include codes of practice, infrastructure investments, and 'industry good' databases as outlined in Table 5. 


\section{Assessing RRI in Relation to NZ Smart Dairying Development and Associated Socio-Ethical Challenges}

In this section, we use the RRI framework (Table 1) to understand past RRI-related R\&D activities and initiatives and how they connected to emerging socio-ethical concerns in smart dairy development. Also, we identify gaps in terms of RRI, and on the basis of these gaps we identify potential RRI issues and opportunities for researchers, policymakers, private companies, and society relating to smart farming in the context of NZ's dairy industry. There are limited explicit processes to identify and manage socio-ethical factors in the current NZ R\&D structure, but these may be addressed at a research organisation level via human ethics approval processes. Also, stakeholder engagement has become a common early phase of large projects, and some funding application formats provide an opportunity for identification and management of socio-ethical factors. Furthermore, Maori (indigenous Polynesian people of New Zealand) input is included in all major government-funded research through the Vision Matauranga, a policy to include the innovation potential of Maori knowledge and people in R\&D projects. Although RRI has not been specifically applied in NZ smart dairying R\&D projects (many started before the RRI approach became well known), in this study we identified several aspects of RRI present in project activities but found that these were not conducted in an integrated and comprehensive manner. In Table 6, we summarise what has been done in terms of RRI to address socio-ethical challenges, and we consider how to incorporate missing aspects of RRI in future smart dairying in NZ.

\section{Anticipation}

The informants noted some socio-ethical dilemmas relating to potential future implications of smart dairying use. One related to farmers and their farm teams relying on technology, with the potential consequence of future deskilling of staff in animal handling and decision making. It was suggested that this could lead to some farmers resisting technology adoption. Building farmers' and service providers' capacity to use technology and data appropriately was also seen as a challenge, and one informant noted:

The market size (in NZ) limits investment in technical staff training. [Smart farming researcher 2, 2017]

Another dilemma identified in relation to the need for foresight was the potential implications of reliance on technology for future farmers, particularly if there was technology failure, such as a power failure or internet disruption.

Our analysis identified limited activities relating to the anticipation indicators (Table 6). Surveys examining NZ dairy farmer use of smart technologies (P4, 10) provided a baseline of technology adoption, along with data collected about which technologies farmers thought were most useful and which were on their 'wish list'. The surveys provided some level of engagement in foresight exercises around onfarm adoption and potential barriers and enablers (Indicator 1); however, they did not explore socio-ethical aspects such as skill and labour changes. This study's 
Table 6 Smart dairying R\&D activities relating to indicators of responsible research and innovation (based on a review of previous studies and insights from informants)

\begin{tabular}{llll}
\hline $\begin{array}{l}\text { Indicator } \\
\text { (number in } \\
\text { brackets) }\end{array}$ & $\begin{array}{l}\text { Past and current RRI- } \\
\text { related activities }\end{array}$ & $\begin{array}{l}\text { RRI gaps: tensions and } \\
\text { lessons related to these } \\
\text { activities in light of RRI }\end{array}$ & $\begin{array}{l}\text { Recommendations for } \\
\text { future RRI activities }\end{array}$ \\
\hline
\end{tabular}

\section{Anticipation}

(1) Foresight exercises

2) Scenario building of smart dairy futures

\section{Limited evidence of scenario building (P8)}

Precision dairy project discussed future needs with farmers and technology developers (P8)

Social scientist embedded in the precision dairy project (P6)

Limited foresight activities, e.g. the precision dairy strategy (P8)

\section{Inclusion}

(3) Involvement of relevant actors

Involvement of end-users (primarily farmers) in technology development discussions, e.g. including farmers and technology developers as stakeholders in R\&D projects, through steering committees, workshops, and surveys (P4, 6, 7, 8, 10)
The fast-moving smart farming domain requires regular foresight discussions

Precision dairy strategy (P8) is over 5 years old; the community's view of farmers has evolved in this time

Limited interaction with farm advisors and other networks to understand issues of changing advisory relationships

Scenario building may occur in areas not identified in our analysis (e.g. commercial R\&D)

Issues such as future use of data and implications of OVERSEER ${ }^{\mathrm{TM}}$ need to be explored via future-casting

Minimal public debate or deeper consideration at national policy level on issues such as increased influence of technology companies on farmer access to data

The next 5 years are a pivotal time to include society in designing the future of smart dairying because of increased uptake

Including citizens effectively is difficult, therefore CSOs may need to be used as a proxy
Include foresight exercises in scoping stages of project development and in the start-up phase of long-term projects

Involve social scientists as participants (e.g. as reflexive monitors, see below)

Use 5-yearly technology survey to assess farmer perceptions of smart dairying issues and implications-consider running survey biennially

Involve technology developers and community/ consumers in scenario building

Include processes to imagine future farming scenarios, e.g. (Shadbolt et al. 2017)

Include community representatives or relevant CSOs on project steering committees

Use forums to include citizens, e.g. Weary and von Keyserlingk (2017)

Instigate open innovation protocols to enable the inclusion of smaller technology providers and other service providers 
Table 6 continued

\begin{tabular}{llll}
\hline $\begin{array}{l}\text { Indicator } \\
\text { (number in } \\
\text { brackets) }\end{array}$ & $\begin{array}{l}\text { Past and current RRI- } \\
\text { related activities }\end{array}$ & $\begin{array}{l}\text { RRI gaps: tensions and } \\
\text { lessons related to these } \\
\text { activities in light of RRI }\end{array}$ & $\begin{array}{l}\text { Recommendations for } \\
\text { future RRI activities }\end{array}$ \\
\hline
\end{tabular}

(4) Private sector Some R\&D projects ( $\mathrm{P} 1$, engagement

(5) Encouraging transformative mutual learning

\section{Reflexivity}

(6) Reflexive guidance

Projects (P6, 7) included social scientists and

\section{$2,7)$ were designed to} include the private sector and therefore deal with issues such as intellectual property

Some projects brought private company representatives together to discuss issues such as data exchange and acceptable technology performance

No evidence was seen of specific mutual learning processes within the R\&D projects analysed

\section{Balancing public and private interests highlighted tensions around intellectual property, trust, and open innovation \\ New technology companies are rapidly emerging, need to include them in long- term projects}

User-centred design methodologies used in the commercial sector have not included the wider community. Reflexive interactive design and participatory modelling have been used in non-technology dairy projects

Potentially user-centred design has been viewed as too risky for $\mathrm{R} \& \mathrm{D}$ funding agencies farm systems experts

Focused inward to understand the implications for farmers and networks

Social science in the R\&D programmes has sought to address some of the tensions

Wider interactions between technology and society have not been
Smaller start-up companies should be represented, requiring flexibility on $5+$ year projects, as the relevant start-ups may not be present at the project outset

Apply participatory processes in future $R \& D$ projects

Include community and socio-ethical perspectives

Funding agencies need to understand the potential gains from mutual learning processes addressed
Focus reflexivity activities outward to examine the community and consumer implications, particularly at the start of $R \& D$ projects

Greater researcher reflection required to incorporate perspectives of all actors

Requires multidisciplinarity and co-development, commitment to reflexivity (Ayre and Nettle 2015) 
Table 6 continued

\begin{tabular}{llll}
\hline $\begin{array}{l}\text { Indicator } \\
\text { (number in } \\
\text { brackets) }\end{array}$ & $\begin{array}{l}\text { Past and current RRI- } \\
\text { related activities }\end{array}$ & $\begin{array}{l}\text { RRI gaps: tensions and } \\
\text { lessons related to these } \\
\text { activities in light of RRI }\end{array}$ & $\begin{array}{l}\text { Recommendations for } \\
\text { future RRI activities }\end{array}$ \\
\hline
\end{tabular}

\begin{tabular}{|c|c|c|c|}
\hline $\begin{array}{l}\text { (7) Structures } \\
\text { guide second- } \\
\text { order } \\
\text { reflexivity }\end{array}$ & $\begin{array}{l}\text { Establishment of Farm } \\
\text { Data Standards and a } \\
\text { Farm Data Code of } \\
\text { Practice (N3) } \\
\text { Development of precision } \\
\text { dairy strategy (P8) } \\
\text { Standards were applied } \\
\text { at the technology- } \\
\text { specific level }(\mathrm{P} 11,12)\end{array}$ & $\begin{array}{l}\text { Power relationships } \\
\text { between farmers and } \\
\text { companies, and between } \\
\text { companies, indicates a } \\
\text { need for codes of } \\
\text { conduct on transparent } \\
\text { data use } \\
\text { Standards developed in } \\
\text { NZ smart dairying are } \\
\text { voluntary, with limited } \\
\text { use potentially because } \\
\text { of insufficient value } \\
\text { proposition for } \\
\text { technology companies } \\
\text { Current codes of conduct } \\
\text { and standards are } \\
\text { designed for technology } \\
\text { development, rather than } \\
\text { for research practice }\end{array}$ & $\begin{array}{l}\text { Extend codes of conduct } \\
\text { and standards beyond a } \\
\text { technology focus to } \\
\text { incorporate ethical } \\
\text { codes of conduct, } \\
\text { particularly for research } \\
\text { and innovation practice } \\
\text { Potential role for } \\
\text { government technical } \\
\text { advisory group (N12) in } \\
\text { identifying and } \\
\text { championing open data } \\
\text { processes and } \\
\text { transparency } \\
\text { Standards around data } \\
\text { ownership and transfer } \\
\text { may need to be } \\
\text { compulsory }\end{array}$ \\
\hline
\end{tabular}

\section{Responsiveness}

(8) Potential to adapt projects

\section{(9) Open research processes and access to research data}

Several projects $(\mathrm{P} 6,7,8)$ Stage-gating decisions had the ability to change were based on direction, based on stakeholder feedback (funders or farmers, not community actors), and had stage-gating provisions

$$
\begin{aligned}
& \text { Large smart dairy R\&D } \\
& \text { projects publicly } \\
& \text { provided short annual } \\
& \text { updates (P6, 7) } \\
& \text { Release of research data } \\
& \text { occurred in some } \\
& \text { instances (P11, 12) but } \\
& \text { was not widespread }
\end{aligned}
$$

technology feasibility rather than ethical considerations

Recent investment in internet and low power network infrastructure suggests more rapid change, creating a greater imperative for responsiveness in $\mathrm{R} \& \mathrm{D}$ project design

A major gap was the public release of research plans and progress (such as seen in the IoF2020 and GREAT EU projects)

A socio-ethical tension involved the power of companies to control access to trial results, in the name of protecting intellectual property
Extend stage-gating to consider issues such as long-term impacts (positive and negative) and socio-ethical implications for dairy farming issues

Large PGP-style projects should adopt a research framework of public release of project designs and progress reports 
analysis of $\mathrm{R} \& \mathrm{D}$ projects highlighted a need for greater embedding of anticipation methodologies within projects, such as scenario building (Indicator 2). One issue identified by informants was differences in worldviews and issues of power among actors (farmers, private companies, organisations, citizens, and consumers) involved in smart dairying in NZ. For example, the evolving power relationships between farmers and private companies in NZ, identified during interviews, centred on data collection and use, where data ownership was uncertain. This issue arose because some companies saw data as an asset to capture and control.

An issue not addressed in anticipation activities, but that would need attention according to informants, is contemplating the use of smart dairying data, for example in the nutrient accounting software OVERSEER ${ }^{\mathrm{TM}}$ (P9). Informants indicated that the end use of such data (e.g. for environmental regulation) should be made transparent when data are being collected. In NZ, we identified activities such as the creation of Farm Data Standards (N3), which aimed to clarify data ownership and transfer, and thereby address these issues (Indicator 7). The Government's technical advisory group could fill the identified gaps in anticipation and responsiveness activities by leading discussions on appropriate transparency of data use.

\section{Inclusion}

Some inclusion-related activities were identified, with the inclusion of farmers and technology developers in $\mathrm{R} \& \mathrm{D}$ projects (e.g. P1, 6, 7, 12) via workshops, both about general smart dairying issues and about specific topics such as use of individual feeding and walk-over weighing. Through these inclusion processes, the interaction and evolving power relationships between private companies and farmers were identified as significant tensions in smart dairying in NZ. Several of the R\&D projects identified farmer frustration at poor access to their data and the lack of easily transferable data between the different software platforms of different companies (P4, 6, 8, 12). One informant noted that:

No one has cracked seamless integration of data. [Milk processor representative 2, 2017]

Data integration was noted as an ongoing dilemma for more effective technology use. Several of the R\&D projects (P6, 8, 11, 12) identified the tensions among private companies associated with smart dairying operating in NZ, as the companies compete to gain market share within a small dairy market. Informants noted that many of the large dairy processors and technology companies now have a digital strategy; this may exacerbate tensions as companies attempt to find their market niche. This highlights the need for greater private sector engagement in R\&D projects (Indicator 4).

Some public inclusion activities were identified where smart dairying was used to engage the wider public with farming and technology through open days and media articles. However, despite these efforts, our analysis found limited inclusion of the wider community in the development of smart dairying (Indicator 3). Informants indicated that this resulted from a lack of perceived need, combined with the 
difficulty of engaging with community actors. One informant suggested that consumers had a limited understanding of what farmers do and that there was potential for smart technology to help farmers connect to consumers. Another informant commented:

In the past, farmers have said 'I'm a farmer, trust me', but now we need a new level of transparency. [Smart farming researcher 1, 2017]

However, informants also suggested that consumer and community opinion of technology-assisted farming could 'go either way' in the next decade, as technology could be seen as either facilitating more ethical treatment of animals or reinforcing negative perceptions of the industrialisation of agriculture. Although in NZ these socio-ethical tensions have received little research attention, informants indicated that negative perceptions of technology in the future could be especially pertinent around innovations such as virtual fencing and robotic milking within NZ's pasturebased grazing system. It may also exacerbate negative perceptions of modern farming, including the reduced naturalness of animals and reduced tradition in farming systems.

A recommendation for addressing this gap in comprehensive inclusion in smart dairying is for greater inclusion of citizens directly, or indirectly through organisations such as civil society organisations (CSO) (Table 6). Also, informants noted that smart dairying involves large incumbent companies (usually included in Primary Growth Partnership-style R\&D because of their ability to access funding), but one recommendation emanating from our analysis was that smaller start-up companies, increasingly important in the smart dairy innovation system, should also be represented in $R \& D$ projects. Informants noted that user-centred design methodologies were most often used by private $R \& D$ but did include the community (Indicator 5). Increased use of such participatory processes in smart dairying R\&D would help researchers and technology developers understand the wider implications of technology development and provide a platform for foresight exercises.

\section{Reflexivity}

Despite some examples, our analysis identified limited reflexivity practices. As regards Indicator 6, social science was included in some of the R\&D projects; however, social scientists' roles mainly involved assessing farmer adoption factors, rather than roles such as reflexive monitoring (Mierlo et al. 2010) to guide reflection and learning within projects. One informant also noted that, although smart dairying could potentially provide proof of good animal welfare, increased social science was required to:

Understand expectations of consumers on wellbeing of animals [and] development of market expectations of sustainable development. [Smart farming researcher 1, 2017]

We identified some informal standards and protocols developed for technology design criteria, such as mastitis detection (P11) and pasture measurement 
technologies (P12) (Kamphuis et al. 2016; Eastwood and Dela Rue 2017). Also, the Farm Data Standards and Code of Practice projects provided a baseline for reflexivity. A related dilemma identified both by informants and in the reviewed R\&D projects was that, although data were useful for farm management and compliance activities, there were questions around data privacy and the eventual use of data. In the R\&D projects $(\mathrm{P} 6,12)$, tensions were identified between farmers and smart dairying companies in terms of data ownership and use (as described earlier in relation to OVERSEER ${ }^{\mathrm{TM}}$ ). A gap identified was the development of methods to adjust $R \& D$ to address these tensions, an area where greater reflexive monitoring support would have been beneficial (Indicator 6).

\section{Responsiveness}

The potential for rapid technological change, through technologies such as the Internet of things, was identified by informants. This was noted as a tension in terms of responsiveness of $R \& D$ projects and highlights the importance of $R \& D$ projects having the ability to be agile and change direction (Indicator 8). The inclusion of stage-gating provisions, informed by ongoing socio-ethical reflexion and assessment, therefore becomes a vital mechanism for large smart dairy projects. Greater responsiveness was required for innovation actors to react to unintended consequences of innovation. For example, one informant identified OVERSEER ${ }^{\mathrm{TM}}$ as a very important factor in whether farmers would adopt potentially beneficial technologies for water and nutrient management. He noted that this software was not agile enough, because the failure to give the use of a smart technology relevant credit in the model output may be a disincentive for future use.

Some of the smart dairying $\mathrm{R} \& \mathrm{D}$ projects included responsiveness to changed circumstances, for example mid-project stage-gating, but the flexibility in R\&D design concerned technological performance issues rather than social or ethical considerations. One example of mid-project review was the design of a strategy for precision dairy in NZ and Australia, co-developed with farmers and sector representatives (P8). This strategy was then used to guide R\&D in the remainder of the project. However, lack of responsiveness to evolving socio-ethical issues can be noted as a gap here, which could lead to long-term R\&D projects delivering technology solutions that society no longer wants. This could be improved by increased openness of project design and access to results, as suggested under Indicator 9 (Table 6).

\section{Conclusion}

Many of the smart dairying dilemmas identified in our study have also been noted in other studies internationally (Andrade and Anneberg 2014; Butler and Holloway 2016; Carolan 2016; Wolfert et al. 2017). These socio-ethical dilemmas included data privacy and power relations between farmers and companies relating to data acquisition and ownership. Changes to the nature of farming and human-animal relations were also identified as socio-ethical dilemmas, potentially leading to 
farmers and/or society rejecting smart farming technology-based approaches-as noted by Wathes et al. (2008). These insights indicate a need for RRI, and in our analysis we found that several socio-ethical challenges were addressed in smart dairying development (e.g. standard setting, infrastructure building), thus connecting with our proposed RRI indicators. However, our assessment of RRI in smart dairying (Table 6) also highlighted gaps relating to a lack of comprehensive and coordinated attention to the RRI dimensions. For example, the RRI indicators consisted mainly of imagining potential smart dairying futures through scenario building and transformative mutual learning through methodologies such as interactive and user-centred design.

Exploration of the causes for the lack of activity regarding RRI indicators is beyond the scope of this paper. However, some reasons could be rooted in the NZ agricultural innovation system setting. As Macnaghten et al. (2014) argue, interaction patterns and power structures in innovation systems influence how RRI can be enacted, and the NZ agricultural innovation system has been found to have a disconnect between different science projects, dividing science from broader innovation efforts, and also a laissez-faire attitude on the part of government towards innovation (Turner et al. 2016). These run counter to some of the principles of RRI. Furthermore, the strong presence of profit-driven private organisations (often multinational) in smart farming is highly influential in the innovation process - as also highlighted by Eastwood et al. (2017b), Blok et al. (2015), and Wolfert et al. (2017). Informants in our study noted the many companies in the innovation space compete for limited market share, thereby hindering their ability to work collectively as required in RRI. These companies may also seek to move faster than publicly funded $R \& D$ projects allow-an issue in the rapidly evolving information technology-dominated domain.

A lack of citizen inclusion in smart dairying $R \& D$ is notable in NZ smart dairying development, particularly in relation to Indicators 3 and 5. Reasons for this may include the techno-centric science focus of smart dairying development to date and the focus of the NZ public on broader debates around the challenges listed in Table 4, rather than specifically on technology. We identify an imperative for R\&D funders and managers to use RRI as an inspiration to proactively involve citizens in ongoing conversations about smart dairying development. The potential interaction of a technology with society often becomes apparent only after the design phase (Buckley et al. 2017). Therefore, timing the ongoing involvement of citizens is important for constructive and meaningful anticipation (Stilgoe et al. 2013). Including community actors or CSOs in project teams would not provide sufficient legitimacy and engagement unless the project activities and agendas were relevant to the community actors, requiring a wider range of skills among project leaders to facilitate such engagement. Including the public in discussions on smart dairy issues, using tools such as internet forums (crowdsourcing), farm visits, and interactive design exercises explored by other studies (Weary and von Keyserlingk 2017; Ventura et al. 2016; Cardoso et al. 2016) could enable more ethical outcomes in the NZ dairy sector.

By applying the RRI lens to a case study of smart dairying in NZ, we can also identify lessons for the application of future RRI to smart farming more generally. 
These lessons involve diagnosing existing RRI efforts to inform future RRI efforts and developing clarity about leadership and a roadmap to enact RRI. Our study confirms that enactment of RRI dimensions in R\&D projects and other innovation activities requires a comprehensive, iterative, and reflexive process, as also noted by Stahl et al. (2016). Without this, a fragmented effort may emerge, potentially with elements of TA and CSR but not a proactive RRI approach. This may result in overlooking some RRI principles and having RRI as an add-on rather than a core feature of research and innovation, as Blok and Lemmens (2015) have noted. R\&D and innovation projects in smart farming should explicitly design for RRI, and understanding the practical application of RRI indicators will provide insights for R\&D funders and managers to assess RRI readiness and embed RRI principles up front in future projects. Our proposition of nine indicators of responsible smart dairying research and innovation represents a first step towards a translation of generic RRI principles into a functional framework in the smart farming space to assess RRI readiness.

The indicators helped guide our analysis of the R\&D projects and other development activities, and aided the identification of areas where there was limited activity (i.e. RRI gaps), such as limited inclusion of citizen perspectives and limited reflexive practices. Our indicators were preliminary in nature, but they were designed to reflect specific attributes associated with smart dairying, such as the influence of private companies, changes to farmer practice, and community concerns over animal welfare and the environment. In contexts with fragmented application of RRI to smart farming, research providers, funders, and policymakers can use this framework for greater guidance of the comprehensive functional application of RRI. However, as exhibited by Wickson and Carew (2014), further effort is required to refine the indicators interactively and adapt them to specific contexts.

After diagnosing actual RRI efforts, innovation systems actors will require guidance regarding how and where they should embed RRI in R\&D and innovation activities-particularly in contexts where the RRI process is acknowledged only to a limited extent and where innovation systems do not enable collective reflection processes. This will require leadership, for example by government, sector organisations, or funding bodies that have sufficient influence over $R \& D$ and innovation processes to enhance the engagement of a range of actors. Several of the large R\&D projects analysed in this study applied transdisciplinary approaches to integrate private R\&D, but, as highlighted by Blok and Lemmens (2015), a clear value proposition is required to engage these private players sustainably in more open interactive processes. In addition, such leadership should bring in civil society, which in our case study was almost fully neglected. Bringing diverse actors, such as private companies and citizens, together to consider future implications requires a high degree of trust (Asveld et al. 2015), but examples provided in this paper (e.g. P12-workshops with different technology developers) show that, in the right context, this can result in positive interactions. Greater use of existing peer communities (e.g. technology sector representative groups, environmental groups, animal ethics groups), as suggested by Hellström (2003), could help a wide range of actors to engage in RRI activities. 
Where there has been a fragmented approach to RRI, actors will need a form of roadmap combined with coherent project portfolios to address issues relating to the four RRI dimensions to transition towards what Stahl et al. (2016) have referred to as maturity in implementing RRI. In smart farming, such a roadmap and associated project portfolios must link private and public interests in a collective approach. Additionally, following Wolfert et al. (2017) and Bronson and Knezevic (2016), it should promote attention on governance and socio-ethical aspects of issues such as open-source ICT development, data movement between platforms, and protection of farmer privacy. Defining and operationalising this roadmap could be supported by user-centric and design-oriented approaches, for example reflexive interactive design (Bos et al. 2009), design thinking (Pavie and Carthy 2015), and the use of open-source data and innovation (Blok and Lemmens 2015). However, following arguments by Macnaghten et al. (2014) and Klerkx et al. (2017), choosing the exact approach or methodology to enact RRI would also call for a deliberation on how to translate RRI to a specific country context or sector context, given the particularities of its innovation system.

Acknowledgements This study was funded by New Zealand dairy farmers through DairyNZ Inc. in partnership with Ministry for Primary Industries Primary Growth Partnership funding. We thank the reviewers and editors for their useful suggestions which helped us to improve the article.

Author Contributions CE and LK jointly articulated the idea and theoretical framing for the article. MA also contributed to the framing and conceptual development of the article. CE took the lead in the writing and revising the article, with LK giving substantive inputs to content and structuring of the article. CE and BDR did data collection and analysis. MA and BDR gave feedback on iterative versions of the article.

Open Access This article is distributed under the terms of the Creative Commons Attribution 4.0 International License (http://creativecommons.org/licenses/by/4.0/), which permits unrestricted use, distribution, and reproduction in any medium, provided you give appropriate credit to the original author(s) and the source, provide a link to the Creative Commons license, and indicate if changes were made.

\section{References}

Andrade, S. B., \& Anneberg, I. (2014). Farmers under pressure. Analysis of the social conditions of cases of animal neglect. Journal of Agricultural and Environmental Ethics, 27(1), 103-126. https://doi. org/10.1007/s 10806-013-9456-9.

Asveld, L., Ganzevles, J., \& Osseweijer, P. (2015). Trustworthiness and responsible research and innovation: The case of the bio-economy. Journal of Agricultural and Environmental Ethics, 28(3), 571-588. https://doi.org/10.1007/s10806-015-9542-2.

Ayre, M., \& Nettle, R. (2015). Doing integration in catchment management research: Insights into a dynamic learning process. Environmental Science \& Policy, 47, 18-31. https://doi.org/10.1016/j. envsci.2014.10.011.

Ballingall, J., \& Pambudi, D. (2017). Dairy trade's economic contribution to New Zealand (pp. 1-42). Wellington, New Zealand: NZ Institute of Economic Research (Inc).

Blok, V., Hoffmans, L., \& Wubben, E. F. M. (2015). Stakeholder engagement for responsible innovation in the private sector: Critical issues and management practices. Journal on Chain and Network Science, 15(2), 147-164. https://doi.org/10.3920/JCNS2015.x003.

Blok, V., \& Lemmens, P. (2015). The emerging concept of responsible innovation. Three reasons why it is questionable and calls for a radical transformation of the concept of innovation. In B.-J. Koops, I. 
Oosterlaken, H. Romijn, T. Swierstra, \& J. van den Hoven (Eds.), Responsible innovation 2: Concepts, approaches, and applications (pp. 19-35). Cham: Springer International Publishing.

Blok, V., \& Long, T. B. (2016). The role of responsible innovation in the technology assessment of smart farming technologies in Europe. Paper presented at the food futures: Ethics, science and culture, Porto, Portugal, 29 September-1 October 2016.

Boogaard, B. K., Bock, B. B., Oosting, S. J., Wiskerke, J. S. C., \& van der Zijpp, A. J. (2011). Social acceptance of dairy farming: The ambivalence between the two faces of modernity. Journal of Agricultural and Environmental Ethics, 24(3), 259-282. https://doi.org/10.1007/s10806-010-92564.

Borchers, M. R., \& Bewley, J. M. (2015). An assessment of producer precision dairy farming technology use, prepurchase considerations, and usefulness. Journal of Dairy Science, 98(6), 4198-4205. https://doi.org/10.3168/jds.2014-8963.

Bos, A. P., Groot Koerkamp, P. W. G., Gosselink, J. M. J., \& Bokma, S. (2009). Reflexive interactive design and its application in a project on sustainable dairy husbandry systems. Outlook on Agriculture, 38(2), 137-145.

Bos, J., \& Munnichs, G. (2016). Digitalisering van dieren: Verkenning Precision Livestock Farming.[Digitization of animals: Exploration of Precision Livestock Farming.] Rathenau Institute, The Hague.

Bronson, K. (2015). Responsible to whom? Seed innovations and the corporatization of agriculture. Journal of Responsible Innovation, 2(1), 62-77. https://doi.org/10.1080/23299460.2015.1010769.

Bronson, K., \& Knezevic, I. (2016). Big Data in food and agriculture. Big Data \& Society, 3(1), 1-5. https://doi.org/10.1177/2053951716648174.

Bruijnis, M. R. N., Blok, V., Stassen, E. N., \& Gremmen, H. G. J. (2015). Moral "lock-In" in responsible innovation: The ethical and social aspects of killing day-old chicks and Its alternatives. Journal of Agricultural and Environmental Ethics, 28(5), 939-960. https://doi.org/10.1007/s10806-015-95667.

Buckley, J. A., Thompson, P. B., \& Whyte, K. P. (2017). Collingridge's dilemma and the early ethical assessment of emerging technology: The case of nanotechnology enabled biosensors. Technology in Society, 48, 54-63. https://doi.org/10.1016/j.techsoc.2016.12.003.

Burton, R. J. F., Peoples, S., \& Cooper, M. H. (2012). Building 'cowshed cultures': A cultural perspective on the promotion of stockmanship and animal welfare on dairy farms. Journal of Rural Studies, 28(2), 174-187. https://doi.org/10.1016/j.jrurstud.2011.12.003.

Busse, M., Schwerdtner, W., Siebert, R., Doernberg, A., Kuntosch, A., König, B., et al. (2015). Analysis of animal monitoring technologies in Germany from an innovation system perspective. Agricultural Systems, 138, 55-65. https://doi.org/10.1016/j.agsy.2015.05.009.

Butler, D., \& Holloway, L. (2016). Technology and restructuring the social field of dairy farming: Hybrid capitals, 'stockmanship' and automatic milking systems. Sociologia Ruralis, 56(4), 513-530. https:// doi.org/10.1111/soru.12103.

Carbonell, I. (2016). The ethics of big data in big agriculture. Internet Policy Review. https://doi.org/10. 14763/2016.1.405.

Cardoso, C. S., Hötzel, M. J., Weary, D. M., Robbins, J. A., \& von Keyserlingk, M. A. G. (2016). Imagining the ideal dairy farm. Journal of Dairy Science, 99(2), 1663-1671. https://doi.org/10.3168/ jds.2015-9925.

Carolan, M. (2016). Publicising food: Big data, precision agriculture, and co-experimental techniques of addition. Sociologia Ruralis. https://doi.org/10.1111/soru.12120.

Chobtang, J., Ledgard, S. F., McLaren, S. J., \& Donaghy, D. J. (2017). Life cycle environmental impacts of high and low intensification pasture-based milk production systems: A case study of the Waikato region, New Zealand. Journal of Cleaner Production, 140 Part, 2, 664-674. https://doi.org/10.1016/ j.jclepro.2016.06.079.

Clark, D., Litherland, A., Mata, G., \& Burling-Claridge, R. (2006). Pasture monitoring from space. Paper presented at the South Island Dairy Event, Invercargill, New Zealand, 26-28th June 2006.

Dawkins, M. S. (2017). Animal welfare and efficient farming: Is conflict inevitable? Animal Production Science, 57(2), 201-208. https://doi.org/10.1071/AN15383.

Dela Rue, B. T., \& Eastwood, C. R. (2017). Individualised feeding of concentrate supplement in pasturebased dairy systems: Practices and perceptions of New Zealand dairy farmers and their advisors. Animal Production Science, 57(7), 1543-1549. https://doi.org/10.1071/AN16471. 
Doole, G. J., \& Romera, A. J. (2015). Trade-offs between profit, production, and environmental footprint on pasture-based dairy farms in the Waikato region of New Zealand. Agricultural Systems, 141, 14-23. https://doi.org/10.1016/j.agsy.2015.09.005.

Draganova, I., Yule, I., Stevenson, M., \& Betteridge, K. (2016). The effects of temporal and environmental factors on the urination behaviour of dairy cows using tracking and sensor technologies. Precision Agriculture, 17, 407-420.

Driessen, C., \& Heutinck, L. (2015). Cows desiring to be milked? Milking robots and the co-evolution of ethics and technology on Dutch dairy farms. Agriculture and Human Values, 32(1), 3-20. https:// doi.org/10.1007/s10460-014-9515-5.

Eastwood, C. R., Chapman, D. F., \& Paine, M. S. (2012). Networks of practice for co-construction of agricultural decision support systems: Case studies of precision dairy farms in Australia. Agricultural Systems, 108, 10-18. https://doi.org/10.1016/j.agsy.2011.12.005.

Eastwood, C. R., \& Dela Rue, B. (2017). Identification of performance attributes for pasture measuring devices. Journal of New Zealand Grasslands, 79, 17-22.

Eastwood, C. R., Dela Rue, B. T., \& Gray, D. I. (2017a). Using a 'network of practice' approach to match grazing decision-support system design with farmer practice. Animal Production Science, 57(7), 1536-1542. https://doi.org/10.1071/AN16465.

Eastwood, C. R., Jago, J. G., Edwards, J. P., \& Burke, J. K. (2016). Getting the most out of advanced farm management technologies: Roles of technology suppliers and dairy industry organisations in supporting precision dairy farmers. Animal Production Science, 56(10), 1752-1760. https://doi.org/ 10.1071/AN141015.

Eastwood, C. R., Klerkx, L., \& Nettle, R. (2017b). Dynamics and distribution of public and private research and extension roles for technological innovation and diffusion: Case studies of the implementation and adaptation of precision farming technologies. Journal of Rural Studies, 49, 1-12. https://doi.org/10.1016/j.jrurstud.2016.11.008.

Eastwood, C. R., \& Yule, I. (2015). Challenges and opportunities for precision dairy farming in New Zealand. Farm Policy Journal, 12(1), 33-41.

Edwards, J. P., Dela Rue, B. T., \& Jago, J. G. (2015). Evaluating rates of technology adoption and milking practices on New Zealand dairy farms. Animal Production Science, 55(6), 702-709. https:// doi.org/10.1071/AN14065.

Geels, F. (2004). From sectoral systems of innovation to socio-technical systems: Insights about dynamics and change from sociology and institutional theory. Research Policy, 33(6-7), 897-920.

Grandin, T. (2014). Animal welfare and society concerns finding the missing link. Meat Science, 98(3), 461-469. https://doi.org/10.1016/j.meatsci.2014.05.011.

Groves, C. (2017). Review of RRI tools project, http://www.rri-tools.eu. Journal of Responsible Innovation, 1-4, https://doi.org/10.1080/23299460.2017.1359482.

Grunwald, A. (2014). Technology assessment for responsible innovation. In J. van den Hoven, N. Doorn, T. Swierstra, B.-J. Koops, \& H. Romijn (Eds.), Responsible innovation 1: Innovative solutions for global issues (pp. 15-31). Dordrecht: Springer Netherlands.

Guston, D. H. (2014a). Giving content to responsible innovation. Journal of Responsible Innovation, 1(3), 251-253. https://doi.org/10.1080/23299460.2014.972085.

Guston, D. H. (2014b). Understanding 'anticipatory governance'. Social Studies of Science, 44(2), 218-242. https://doi.org/10.1177/0306312713508669.

Hekkert, M. P., \& Negro, S. O. (2009). Functions of innovation systems as a framework to understand sustainable technological change: Empirical evidence for earlier claims. Technological Forecasting and Social Change, 76(4), 584-594. https://doi.org/10.1016/j.techfore.2008.04.013.

Hellström, T. (2003). Systemic innovation and risk: Technology assessment and the challenge of responsible innovation. Technology in Society, 25(3), 369-384. https://doi.org/10.1016/S0160$791 X(03) 00041-1$.

Hemphill, T. A. (2016). Responsible innovation in industry: A cautionary note on corporate social responsibility. Journal of Responsible Innovation, 3(1), 81-87. https://doi.org/10.1080/23299460. 2016.1178896.

Higgins, V., Bryant, M., Howell, A., \& Battersby, J. (2017). Ordering adoption: Materiality, knowledge and farmer engagement with precision agriculture technologies. Journal of Rural Studies, 55, 193-202. https://doi.org/10.1016/j.jrurstud.2017.08.011.

Holloway, L., Bear, C., \& Wilkinson, K. (2014). Robotic milking technologies and renegotiating situated ethical relationships on UK dairy farms. Agriculture and Human Values, 31(2), 185-199. https://doi. org/10.1007/s10460-013-9473-3. 
Iatridis, K., \& Schroeder, D. (2016). Responsible research and innovation in industry: The case for corporate responsibility tools. Cham: Springer International Publishing.

IoF2020. (2017). D1.3 Detailed work plan. Accessed August 15, 2017, from https://www.iof2020.eu/ deliverables/d1.3.-detailed-work-plan.pdf.

Jago, J., Eastwood, C. R., Kerrisk, K., \& Yule, I. (2013). Precision dairy farming in Australasia: Adoption, risks and opportunities. Animal Production Science, 53(9), 907-916. https://doi.org/10. 1071/AN12330.

Jay, M. (2007). The political economy of a productivist agriculture: New Zealand dairy discourses. Food Policy, 32(2), 266-279. https://doi.org/10.1016/j.foodpol.2006.09.002.

Kaloxylos, A., Eigenmann, R., Teye, F., Politopoulou, Z., Wolfert, S., Shrank, C., et al. (2012). Farm management systems and the Future Internet era. Computers and Electronics in Agriculture, 89, 130-144. https://doi.org/10.1016/j.compag.2012.09.002.

Kamphuis, C., Dela Rue, B. T., \& Eastwood, C. R. (2016). Field validation of protocols developed to evaluate in-line mastitis detection systems. Journal of Dairy Science, 99(2), 1619-1631. https://doi. org/10.3168/jds.2015-10253.

Kilelu, C. W., Klerkx, L., \& Leeuwis, C. (2013). Unravelling the role of innovation platforms in supporting co-evolution of innovation: Contributions and tensions in a smallholder dairy development programme. Agricultural Systems, 118, 65-77. https://doi.org/10.1016/j.agsy.2013. 03.003.

Klerkx, L., Seuneke, P., de Wolf, P., \& Rossing, W. A. H. (2017). Replication and translation of coinnovation: The influence of institutional context in large international participatory research projects. Land Use Policy, 61, 276-292. https://doi.org/10.1016/j.landusepol.2016.11.027.

Klerkx, L., van Bommel, S., Bos, B., Holster, H., Zwartkruis, J. V., \& Aarts, N. (2012). Design process outputs as boundary objects in agricultural innovation projects: Functions and limitations. Agricultural Systems, 113, 39-49. https://doi.org/10.1016/j.agsy.2012.07.006.

Kolbach, R., Kerrisk, K. L., García, S. C., \& Dhand, N. K. (2012). Attachment accuracy of a novel prototype robotic rotary and investigation of two management strategies for incomplete milked quarters. Computers and Electronics in Agriculture, 88, 120-124. https://doi.org/10.1016/j.compag. 2012.07.011.

LIC \& DairyNZ. (2016). New Zealand dairy statistics 2015-16. Hamilton: DairyNZ.

Macnaghten, P. (2016). Responsible innovation and the reshaping of existing technological trajectories: The hard case of genetically modified crops. Journal of Responsible Innovation, 3(3), 282-289. https://doi.org/10.1080/23299460.2016.1255700.

Macnaghten, P., Owen, R., Stilgoe, J., Wynne, B., Azevedo, A., de Campos, A., et al. (2014). Responsible innovation across borders: Tensions, paradoxes and possibilities. Journal of Responsible Innovation, 1(2), 191-199. https://doi.org/10.1080/23299460.2014.922249.

Mierlo, B. V., Arkesteijn, M., \& Leeuwis, C. (2010). Enhancing the reflexivity of system innovation projects with system analyses. American Journal of Evaluation, 31(2), 143-161. https://doi.org/10. $1177 / 1098214010366046$.

Millar, K. M. (2000). Respect for animal autonomy in bioethical analysis: The case of Automatic Milking Systems (AMS). Journal of Agricultural and Environmental Ethics, 12(1), 41-50.

Owen, R., Stilgoe, J., Macnaghten, P., Gorman, M., Fisher, E., \& Guston, D. (2013). A framework for responsible innovation. In Responsible innovation (pp. 27-50): John Wiley \& Sons, Ltd. Doi: https://doi.org/10.1002/9781118551424.ch2.

Palm, E., \& Hansson, S. O. (2006). The case for ethical technology assessment (eTA). Technological Forecasting and Social Change, 73(5), 543-558. https://doi.org/10.1016/j.techfore.2005.06.002.

Pavie, X., \& Carthy, D. (2015). Leveraging uncertainty: A practical approach to the integration of responsible innovation through design thinking. Procedia - Social and Behavioral Sciences, 213, 1040-1049. https://doi.org/10.1016/j.sbspro.2015.11.523.

Pellé, S., \& Reber, B. (2013). Governance of responsible innovation-Deliverable 2.2: The theoretical landscape. Accessed August 17, 2017, from https://ec.europa.eu/research/science-society/ document_library/deliverable_2.2.pdf.

Ravn, T., Nielsen, M. W., \& Mejlgaard, N. (2015). Metrics and indicators of Responsible Research and Innovation Progress report D3.2. European Commission, Brussels.

Rutten, C. J., Velthuis, A. G. J., Steeneveld, W., \& Hogeveen, H. (2013). Invited review: Sensors to support health management on dairy farms. Journal of Dairy Science, 96(4), 1928-1952. https://doi. org/10.3168/jds.2012-6107. 
Saunders, C., Dalziel, P., Guenther, M., Saunders, J., \& Rutherford, P. (2016). The land and the brand. AERU Research Report No. 339. Lincoln, New Zealand: Lincoln University. AERU.

Schewe, R. L., \& Stuart, D. (2014). Diversity in agricultural technology adoption: How are automatic milking systems used and to what end? Agriculture and Human Values. https://doi.org/10.1007/ s10460-014-9542-2.

Scholten, M. C. T., de Boer, I. J. M., Gremmen, B., \& Lokhorst, C. (2013). Livestock farming with care: Towards sustainable production of animal-source food. NJAS - Wageningen Journal of Life Sciences, 66, 3-5. https://doi.org/10.1016/j.njas.2013.05.009.

Schrijver, R., Poppe, K., \& Daheim, C. (2016). Precision agriculture and the future of farming in Europe: Scientific Foresight Study. Brussels: European Parliament Research Service.

Shadbolt, N., Apparao, D., Hunter, S., Bicknell, K., \& Dooley, A. (2017). Scenario analysis to determine possible, plausible futures for the New Zealand dairy industry. New Zealand Journal of Agricultural Research, 60(3), 349-361. https://doi.org/10.1080/00288233.2017.1351377.

Skorupinski, B. (2002). Putting precaution to debate: About the precautionary principle and participatory technology assessment. Journal of Agricultural and Environmental Ethics, 15(1), 87-102. https:// doi.org/10.1023/a:1013853425094.

Stahl, B., Obach, M., Yaghmaei, E., Ikonen, V., Chatfield, K., \& Brem, A. (2017). The Responsible Research and Innovation (RRI) maturity model: Linking theory and practice. Sustainability, 9(6), 1036. https://doi.org/10.3390/su9061036.

Stahl, B., Timmermans, J., \& Flick, C. (2016). Ethics of emerging information and communication technologies: On the implementation of responsible research and innovation. Science and Public Policy, 44(3), 369-381. https://doi.org/10.1093/scipol/scw069.

Stilgoe, J., Owen, R., \& Macnaghten, P. (2013). Developing a framework for responsible innovation. Research Policy, 42(9), 1568-1580. https://doi.org/10.1016/j.respol.2013.05.008.

Tey, Y., \& Brindal, M. (2012). Factors influencing the adoption of precision agricultural technologies: A review for policy implications. Precision Agriculture, 13(6), 713-730. https://doi.org/10.1007/ s11119-012-9273-6.

Tipples, R., \& Wilson, J. (2005). The dairy farming population and migrations. Primary Industry Management, 8(1), 41-45.

Turner, J. A., Klerkx, L., Rijswijk, K., Williams, T., \& Barnard, T. (2016). Systemic problems affecting co-innovation in the New Zealand Agricultural Innovation System: Identification of blocking mechanisms and underlying institutional logics. NJAS - Wageningen Journal of Life Sciences, 76, 99-112. https://doi.org/10.1016/j.njas.2015.12.001.

Umstatter, C. (2011). The evolution of virtual fences: A review. Computers and Electronics in Agriculture, 75(1), 10-22. https://doi.org/10.1016/j.compag.2010.10.005.

Ventura, B. A., von Keyserlingk, M. A. G., Wittman, H., \& Weary, D. M. (2016). What difference does a visit make? Changes in animal welfare perceptions after interested citizens tour a dairy farm. PLoS ONE, 11(5), e0154733. https://doi.org/10.1371/journal.pone.0154733.

von Schomberg, R. (2011). Towards responsible research and innovation in the information and communication technologies and security technologies fields. https://philpapers.org/archive/ VONTRR.pdf: European Commission, Brussels.

Wales, W. J., \& Kolver, E. S. (2017). Challenges of feeding dairy cows in Australia and New Zealand. Animal Production Science, 57(7), 1366-1383. https://doi.org/10.1071/AN16828.

Wathes, C. M., Kristensen, H. H., Aerts, J. M., \& Berckmans, D. (2008). Is precision livestock farming an engineer's daydream or nightmare, an animal's friend or foe, and a farmer's panacea or pitfall? Computers and Electronics in Agriculture, 64(1), 2-10. https://doi.org/10.1016/j.compag.2008.05. 005.

Weary, D. M., \& von Keyserlingk, M. A. G. (2017). Public concerns about dairy-cow welfare: How should the industry respond? Animal Production Science, 57, 1201-1209. https://doi.org/10.1071/ AN16680.

Wickson, F., \& Carew, A. L. (2014). Quality criteria and indicators for responsible research and innovation: Learning from transdisciplinarity. Journal of Responsible Innovation, 1(3), 254-273. https://doi.org/10.1080/23299460.2014.963004.

Wiek, A., Foley, R. W., Guston, D. H., \& Bernstein, M. J. (2016). Broken promises and breaking ground for responsible innovation: Intervention research to transform business-as-usual in nanotechnology innovation. Technology Analysis \& Strategic Management, 28(6), 639-650. https://doi.org/10.1080/ 09537325.2015.1129399. 
Wigboldus, S., Klerkx, L., Leeuwis, C., Schut, M., Muilerman, S., \& Jochemsen, H. (2016). Systemic perspectives on scaling agricultural innovations. A review. Agronomy for Sustainable Development, 36(3), 1-20. https://doi.org/10.1007/s13593-016-0380-z.

Wolf, S. A., \& Wood, S. D. (1997). Precision farming: Environmental legitimation, commodification of information, and industrial coordination. Rural Sociology, 62(2), 180-206.

Wolfert, S., Ge, L., Verdouw, C., \& Bogaardt, M.-J. (2017). Big data in smart farming: A review. Agricultural Systems, 153, 69-80. https://doi.org/10.1016/j.agsy.2017.01.023.

Wolfert, S., Goense, D., \& Sørensen, C. A. G. (2014). A future internet collaboration platform for safe and healthy food from farm to fork. In 2014 Annual SRII Global Conference, 2014 (pp. 266-273), IEEE.

Woolford, M., Claycomb, R., Jago, J., Davis, K., Ohnstad, I., Wieliczko, R., et al. (2004). Automatic dairy farming in New Zealand using extensive grazing systems. In Proceedings of an International Symposium on Automatic Milking: A Better Understanding, 2004 (pp. 280-285).

Yeates, J. W. (2017). How good? Ethical criteria for a 'Good Life' for farm animals. Journal of Agricultural and Environmental Ethics, 30(1), 23-35. https://doi.org/10.1007/s10806-017-9650-2. 